\title{
NIETZSCHE AND ANTHROPOMORPHISM
}

GEORGE J. STACK

S.U.N.Y. at Brockport

One of the many themes that run through Nietzsche's kaleidoscopic writings is the powerful influence of anthropomorphism upon our conceptions of truth and reality. The "humanization" of the world for the sake of life and the "humanization" of nature for the sake of mastery of it are central points in Nietzsche's thought. In some of his earliest writings he examined the language and concepts that we take for granted and accept uncritically under his sceptical microscope. He detected traces of an apparently inevitable tendency to describe and understand the non-human in terms of human attitudes, sentiments, drives or feelings. Nietzsche continually raises sceptical doubts about our capacity to understand anything at all except in terms of notions that are derived from our own social relations, our own self-reflection or the language we use to describe the "self". Nietzsche's attitude towards the tendency to anthropomorphism in human thought is by no means unambiguous. It evolves and develops up to the point at which he accepts its inevitability and presents his own conception of reality as "will to power" precisely on the basis of a consciously adopted anthropomorphism. It is my concern here to show how the anthropomorphism he so keenly uncovered in the thought of others haunted his attempt to transcend the human standpoint and achieve a vision of a putative, deanthropomorphic "reality".

The first sign of a scepticism concerning man's capacity to discover or express "the true essence of things" is seen in the unpublished essay, "On Truth and Lying in An ExtraMoral Sense". Nietzsche sketches a picture of men as "clever 
animals" whose existence amounts to a moment in cosmic history. The "arrogant" claim to possess knowledge is reduced to the invention of knowledge shaped by the "human intellect" for the sole purpose of preserving and conserving "the life of man". The intellect is compared to the defensive and aggressive weapons of animals and is said to be primarily an "art of simulation". The "enigmatic urge for truth" is said to have begun when men banded together in social groupings. Even though man, for the sake of survival, desires "the agreeable life-preserving consequences of truth", he has no interest in "pure knowledge". Insofar as the expression of 'truth' depends upon "conventions of language", it is necessarily affected by them.

Unsatisfied with the "empty shells" of tautological truth, man seeks to use language to express "realities". However, the creators and users of language find that the Kantian notion of the "thing in itself" is incomprehensible and, therefore, realize that they do not express "pure truth". Since Nietzsche accepts, in this early essay, Kant's distinction between things in themselves and the "appearances" that are constituted by our sensibility and understanding, he suggests that language cannot represent the 'true' nature of things. Even though he later attacks the Kantian notion of "things in themselves", Nietzsche never abandons the position that language is unable to "picture" or describe reality. Language cannot express "pure truth". It can only be used to designate "the relations of things to man" and to express such relations in metaphorical terms. Natural languages preserve the artificial and arbitrary abstractions that bracket individual differences and express a gross simplification of our immediate experience of actuality.

Even though we are not acquainted with "essence-like" qualities in our concrete experience, natural languages preserve and express them. Truthfulness is primarily a socially determined convention that requires that we use "customary metaphors". After arguing that language is unable to express the truth of things, Nietzsche feels entitled to tell us what, 
in his view, 'truth' is. "A moving army of metaphors, metonyms, and anthropomorphisms." It is, in effect, a "sum of human relations" that is "enhanced, transposed, and embellished poetically and rhetorically." Over a period of time these linguistic habits begin to solidify, to become "canonical, and obligatory for a people". We are unable to describe, picture or express the "essence of things" because of the anthropomorphisch nature of our assertion or statements. ${ }^{1}$ If language universalizes what it refers to, if it employs arbitrary abstractions and metaphors, and if it is pervaded by anthropomorphic terms or references, then it cannot be said to express the way of things. In addition, if language perpetuates a conceptual schema that abstracts, simplifies and incorporates fallacious "identities", then it cannot be said to "correspond" to the actualities encountered in lived-experience. One of the implications of Nietzsche's analysis of language is a critique of the correspondence theory of truth.

Nietzsche offers three reasons why language is inadequate to 'picture' actuality. (1) Languages use abstractions and simplifying assumptions of "identity" and are unable to be used to describe the richness, diversity and complexity of immediate experience. (2) Language employs metaphors and anthropomorphisms that yield a poetic, humanized picture of actuality that is presumably 'false'. (3) Language is used to describe "appearances" that are constituted by our "organization" and cannot be used to describe "things in themselves". Finally, if language has the structure that Nietzsche attributes to it, then the attempt to express "truth" by means of it is undermined.

What Nietzsche says about ordinary uses of natural languages is also said about the linguistic expression of metaphysical "truths". In the course of discussing the concept of Being in ancient Greek philosophy, he remarks that "man imagines the existence of other things by analogy with his own existence, in other words anthropomorphically and, in

1. Werke in Drei Bänden, ed. K. Schlechta, Munich, 1966, III, 313-314. 
any case, with non-logical projection". ${ }^{2}$ This claim is, I believe, a key to an understanding of the later postulation of a "will to power" as the ultimate principle of explanation. In his early writings Nietzsche was concerned to expose the anthropomorphic nature of both ordinary language and the language of metaphysics. In The Birth of Tragedy this critique of language is not present insofar as Nietzsche clearly embraced a poetic-metaphysical language uncritically and tried to penetrate to the ineffable reality of the "primal will" (Urwille), conceiving of the existence of the world and our phenomenal being as "a continuously manifested representation of the primal unity". ${ }^{3}$ In this regard, he seems to have sought to discern the true essence of things or the ultimate nature of the "thing in itself". However, once the romantic episode of The Birth of Tragedy was over, Nietzsche's scepticism went into high gear. Shortly after the publication of this aesthetically conceived work, he attacks conventional assumptions about truth in On Truth and Lying in an ExtraMoral Sense (1873) and adopts an agnosticism about the metaphysical claims to truth he examines in Philosophy in the Tragic Age of the Greeks (1873). Throughout his philosophical career Nietzsche grapples with the tension between restricting "knowledge" to the appearances that are conditioned by our psycho-physical "organization" and the desire to push his reflections beyond "appearances" to a metaphysical completion. Both poles of his thinking, however, are affected by the very anthropomorphism that he unconvered in ordinary and philosophical language. It is not the case that when Nietzsche attacks "knowledge" or "truth" he is only concerned with denying "the possibility of any transcendent knowledge, in Kant's sense". And the correlative observation that he does not reject "empirical knowledge" is equally unjustified." In order to show why such claims are misleading or false, it will be necessary to examine Nietz-

2 Ibid., 391.

3 Die Geburt der Tragödie, 4. 
sche's critical analysis of the scientific interpretation of "the world".

During his so-called "positivistic" period, Nietzsche turned his attention away from metaphysics and held that such questions should be put "on ice". Especially in Human, All-TooHuman he praised the precision of the methods of the sciences and valued the search for "little, unapparent truths". The "scientific spirit" is also praised for its tenacity in pursuing "truths" that are often inexpedient or unpleasant. In a field close to his heart (philology) he respected the precise, accurate and unprejudiced interpretations of texts. He was especially impressed by the discipline of science that refrains from grandiose metaphysical leaps of thought and is able to function with provisional assumptions, working hypotheses and regulative principles.

Despite his admiration for science and its "strict methods", Nietzsche was repulsed by the dogmatic "positivists" of the nineteenth century and by their optimistic belief that they had attained objective truth and a clear explanation of the world. Having dissociated himself from his own "temporary attack" of "romanticism", Nietzsche was not anxious to embrace a scientific metaphysics. Rather, he focused on the value of scientific methodologies, the piecemeal approach to knowledge and the healthy respect for the senses in scientific inquiry. As his recurring scepticism examines the concepts and principles of the sciences, however, he begins to see the faint impression of the same anthropomorphism he had previously found in man's attempts to describe ultimate reality in metaphysical terms. He saw, in other words, that even the strict empirical sciences do not really give us a purely objective, unprejudiced picture of "reality".

The scientific understanding of the natural world is an "interpretation". It is a process analogous to the hermeneutic method of the philologist: the scientist interprets the "text" of nature in a manner resembling the philological interpreta-

4 J. T. Wilcox, Truth and Value in Nietzsche, Ann Arbor, 1974, 124. 
tion of a written text. Such an interpretation is guided by fundamental assumptions, by categorical schema that, like Kant's categories of the understanding, are useful, "conventional fictions". Basic concepts employed in the sciences are construed as "regulative fictions" that are pragmatically and heuristically useful, but are not 'true'. There are no uninterpreted pure facts discovered in science. It is our sensorycognitive "organization" that constitutes the data examined by the sciences. The "assumptions of mechanics" are based upon ideal inventions such as the idea of "force residing in mathematical points and mathematical lines". Causality is not 'true' of the processes occurring in the world. Rather, it is "an hypothesis by means of which we humanize the world". Nietzsche appeals to Kant in his claim that laws of nature are not discovered in nature. For, they are, as "Kant says", prescribed to nature. That is, "reason does not derive its laws from nature".?

Despite his often vitriolic criticisms of Kant, Nietzsche adopts a conventionalist interpretation of scientific concepts and principles that is clearly derived from his understanding of the implications of Kant's critical analysis of knowledge and his emphasis upon the creative, constructive activity of the mind. Because of his epistemic commitment to the notion that our sensibility and our psychological make-up condition the objects of our 'knowledge', Nietzsche extends this assumption into the domain of science by arguing that the scientist employs constructs in order to "describe" (not explain) appearances. The strand of phenomenalism that runs through Nietzsche's thought encompasses scientific claims to knowledge and is construed as entailing an ineluctable anthropomorphism. For, every claim to discover the nature of things is affected by "human optics". 8 Despite the fact that the sciences appear to transcend this standpoint, scientific "world-

э Werke, Leipsig, 1901, XII, 33.

6 Ibid., XIII, 59.

7 Ibid., II. $36 \mathrm{f}$.

8 Ibid,, XI, 180. 
interpretation" is also infected by "the anthropomorphic element in all knowledge".

Knowing is construed as a simplifying, organizing schematization, a way of "arranging" the phenomena encountered in experience in such a way as to depict a world "for us". The scientific representation of the world is a cognitive system of symbolization, a "semiotics" that is ultimately derived from our selective sensory experience and our psychic nature. It is for purposes of "calculation" that we use notions such as "force", "number", "unit", "atom" and "object". Such concepts are practical, useful fictions. "The inventive power that creates categories is working in the service of our needs, namely of security and rapid intelligibility on the basis of conventions and signs." 10 The various sciences provide us with a "plurality of interpretations" that is a sign of intellectual strength. But precisely because of the hypothetical, provisional, not to say "fictional", nature of the concepts and principles employed in science, they cannot be said to provide an objective "picture" of reality.

Nietzsche's form of instrumental fictionalism entails the belief that virtually all of the terms used in scientific claims to knowledge are, in the broadest sense, anthropomorphic. Neither the categories of the understanding nor the categories employed in scientific thought reflect the reality of things. They serve to coordinate the manifold of our sensory experiences or observations. Both general categories of thought and scientific categories perform the same function: the humanization of our experience. ${ }^{11}$

The formulation of categories of the understanding is accepted by us because of its practical, functional value for the preservation of the species. Science, too, ultimately has a practical purpose: "to humanize the world", ${ }^{12}$ to create an

9 Ibid, $\mathrm{X}, \mathrm{I2I}$.

10 Ibid., XIII, 55.

11 Rudolf Eisler, Nietzsches Erkenntnisstheorie und Metaphysik, Leipsig. $1902,21$.

12 Werke in Drei Bänden, III, 428. 
intelligible, familiar world of phenomena that we can master. Nietzsche conceives of the pursuit of scientific knowledge as the pursuit of power over nature, as an instrument for the technological transformation of the world. The aim of all knowledge is to serve life and the enhancement of life. The world (or, more accurately, "worlds") that is shaped, simplified, arranged and organized by man's sensory-cognitive "organization", by his concepts and languages, by philosophical and scientific categories is necessarily a "humanized world". In this sense, Heidegger is correct in saying that Nietzsche's philosophy is "anthropomorphy — the shaping and viewing of the world in accordance with man's image". ${ }^{12}$ It is misleading, however, to suggest that Nietzsche arrives at such a view by a kind of arbitrary, willful fiat. Rather, it is his probing analyses of philosophical and scientific knowledge-claims, of ordinary and technical language and the influence of our psyche on our thinking that lead him to admit the necessity of "anthropomorphy". Nietzsche's sceptical, critical epistemological analyses led him to the conclusion that, in the final analysis, thought cannot transcend the human standpoint or escape its anthropocentric perspective.

This assumption of the inevitability of anthropomorphic interpretation is central to the "hypothesis" of a "will to power" as a metaphysical principle of explanation. The road to the postulation of the will to power can be traced on the map of Nietzsche's writings. He first found it present in the ancient Greeks, in what he considered as their "lust for power". He at once lamented its absence from the world of his day and saw its ugly side. In an unpublished essay, "Homer's Contest", he characterizes the early Greeks as seeing all of life as an agon, a "contest", a struggle for "more and more". Greek mythology reveals a people for whom "combat is salvation", a people who would seek to rival the power of the gods in their overweening pride (hubris). This striving for dominance and fame inevitably leads to the destruction

13 Martin Heidegger, Nietzsche, Pfullingen, 1961, II, 127. 
of those who engage in it. In comparison to "modern humanity", the figures in Greek myth and history seem bold, daring and heroic. On the other hand, they have a shocking capacity for violence and cruelty. ${ }^{14}$ Even though the expression "will to power" is not used in this essay, it certainly seems to be implied. Its manifestation in individuals generates in Nietzsche the typical ambivalent responses that can be found sprinkled throughout his writings. The converse of the admiration for the energy and daring of the early Greek figures is the realization that the "worship of success" and victory in this world is also a sign of "meanness". To discover in world history the "realization" of the good and the just is, in fact, a "blasphemy against the good and the just". It is often the "universal law" that the strong win in the world. But, Nietzsche laments, "if only it were not so often precisely what is stupid and evil!". ${ }^{15}$

By the time Nietzsche uses the expression "will to power" in Thus Spake Zarathustra, he asserts that the essence of man is will to power. Wherever he found living beings he found "will to power". By emphasizing that Wo ich Lebendiges fand, da fand ich Willen zur Macht, it is clear that he has not yet conceived of a striving for power as immanent in the inorganic world or is not yet willing to express such a view. Growth itself is assumed to be a sign of the presence of this urge for power in the organic world. In an obviously anthropomorphic, not to say animistic statement, it is said that "the trees of a primeval forest struggle" not "for hapiness", but "for power". ${ }^{16}$

The most impressive uncovering of the will to power is found in Nietzsche's psychology. He discerned, as others after him have, a striving for dominance, control and mastery on the part of individuals that was, typically, motivated by feelings of powerlessness. He believed that the pursuit of wealth,

14 Werke in Drei Bänden, III, 291-299.

15 Werke, Munich, 1920-1929, VI, 334f. Cited in The Portable Nietzsche, ed. W. Kaufmann, New York, 1954, 39.

16 Werke, Grossoltavausgabe, Leipsig, 1894-1904, XVI, 164. 
position, prestige and dominance in any form is an expression of a striving for power and more power. The weak use indirect, cunning means in order to attain the same goal. In effect, the primary motive for human behavior was understood as a relentless urge for power even at the expense of others. There is no doubt that this psychological interpretation of human behavior was the dominant model for the general notion of a universal Wille zur Macht. ${ }^{17}$

It is important to realize that, as Kaufmann has correctly pointed out, the earliest allusions to a will to power are expressed in critical terms that clearly indicate disapproval of an unfortunate human tendency. But the other side of the coin is that Nietzsche also expressed very early in his life a certain fascination with the pure expression of power in inorganic nature. In a letter to a friend he remarks that the "pure will" of natural forces (lightning, thunder, hail, etc.) is an impressive display of "free powers". ${ }^{18}$ Even though no theoretical significance is given to this observation, it is clear that the extension of a will to power into the realm of inorganic processes is not a product of his so-called "later" philosophy. Rather, his theory of the universality of the will to power complements sentiments he expressed in the earliest stages of his reflection and coheres with his discovery of a psychological will to power in man.

Sensation and Anthropomorphism

One of the primary reasons why Nietzsche repeatedly refers to our "falsification" of the world is because he took seriously the agnostic implications of Kant's theory of knowledge, as well as the factual data concerning the physiology of sensation that was available to him when he first began to philosophize in earnest. In Schopenhauer as Educator he expressed sympathy with the reaction of von Kleist to the implications of the Kantian philosophy. He remarks that if Kant's thought

17 Walter Kaufmann, Nietzsche, New York, 1968, 184-185.

is Werke in Drei Bänden, III, 962. 
suffuses popular thought, it will be in the form of a "corroding skepticism and relativism". He emphatizes with von Kleist's lament that if we take Kant seriously, then "We cannot decide whether what we call truth is really truth, or whether it merely appears as such to us". ${ }^{19}$ For a time, the philosophy of Schopenhauer was a bulwark against such scepticism and a support for a tragic interpretation of existence. However, a renewed, careful study of current theories of sensation and perception discussed in F. A. Lange's History of Materialism fired Nietzsche's scepticism.

The brief comments on sensation in On Truth and Lying in an Extra-Moral Sense show the influence of then current theories of the physiology of the senses. For, Nietzsche argues that when we sense, say, the color red, we undergo a stimulation of the nervous system. Then a sensation of the color red occurs. The sensation of the color red has no specific relation to what we would now call the brain-state that occasions it. We have, then, no reason to assume that this sensation resembles the stimulus that causes the sensation. We designate this sensation to ourselves and to others by means of a specific sound. Again, what is the resemblance of this word ("red") to the actual color itself or to the experience of the color? The word "red" is said to be a symbol or sign or a metaphorical signification of the color experienced in sensation. Our sensory experience and our judgment about it belong to an entirely different sphere than does the "object" that we assume gave rise to our sensation. ${ }^{20}$ Our concepts are said to be residual metaphors that are used to represent the original sensory experience. But they have no true resemblance to the qualitative uniqueness of our original experience. Therefore, the words we use to express concepts that are intended to describe or 'picture' what we experience by means of our senses cannot resemble the immediacy of lived-experience.

19 Schopenhauer als Erzieher, sect. III.

so Werke in Drei Bänden, III, 312-313. 
That the above interpretation of sensory experience is indebted to then current theories is clear when we compare Hermann Helmholtz's very similar analysis:

So far as the characteristic quality of our sensation informs us of the peculiar nature of the outer influence that excites it, it may pass as a sign of it, but not as a copy ... A sign need have no sort of resemblance to that of which it is a sign. The relation between the two consists simply in the fact that the same 'object' under the same conditions elicits the same sign. ${ }^{21}$

Helmholtz gives a Kantian interpretation to his account of sensation insofar as he claims that our sensations are presumed to be "caused" by processes or objects about which we know nothing at all. Attempts to account for the original cause of sensory experience can only be couched in the form of hypotheses or postulations. Lange reinforces this Kantian interpretation of Helmholtz's theory of the physiology of sensation by maintaining that "colors, sounds, smells ... do not belong to things in themselves, but ... are peculiar forms of excitation of our sensibility, which are called forth by corresponding but qualitatively very different phenomena in the outer world". ${ }^{22}$

Even though Nietzsche does not accept the Kantian understanding of sensibility as passively receptive to "impressions", he does accept the implications of Lange's Kantian conclusion that "the sense-world is the product of our organization". ${ }^{23}$ If, as Lange says, the sense-world is truly the "product" of our sensory-cognitive "organization", then the world we experience is a world for us, a world constituted

21 Hermann Helmholtz, Physiologische Optik, sect. 26. Cited in W. M. Salter, Nietzsche the Thinker, New York, 1917, 483.

22 F. A. Lange, The History of Materialism, trans. E. C. Thomas, London, 1925, iii, 217.

${ }^{23}$ In a letter to his friend Carl von Gersdorff (August, 1866) Nietzsche quotes this statement from Lange's history of materialism and identifies it as one of Lange's chief conclusions. Cf. Werke in Drei Bänden, III, 970. 
by our senses, as well as by the "conventional language" that man, collectively, uses in order to describe the phenomena experienced. Nietzsche concludes that "our senses have wrapped us up in a tissue" of falsifying sensations that, in turn, "lie at the basis of our judgments and our "knowledge". In this sense, then, we have no veridical access to "reality". That is, "We are like spiders in our own webs, and, whatever we may catch in them, it will only be something that our web is capable of catching". ${ }^{24}$

Sensation is understood as an activity that involves inference, that is affected by synthesizing processes that come to fruition in conceptual thought. The sensory process is active because we do not merely passively receive "sense-impressions". Rather, there is a form-giving activity (Formen-Aufzwingen) in sense-experience that is selective, simplifying, that is conditioned by interest, feelings, drives and impulses. It is for this reason that it is held that the world upon which our "eye" and our "psychology" have acted is a world for us, a world that we have shaped by our senses for the sake of simplification and the satisfaction of our pragmatic needs. Now, if "all our categories of reason are of sensual origin", if they are derived from "the empirical world" we experience, ${ }^{25}$ then the external world that we "know" is an elaborate construction, a constituted world that is structured in accordance with the limitations of our senses. The "coarseness" of our sensory organs determines the limits of the sensory apprehension of "reality" and the range of our senses is limited insofar as we are acquainted with phenomena (magnetic fields, electromagnetic waves, ultra-violet waves, etc.) that are not directly perceived. In sum, then, the qualitative world we experience through the sensory modalities belongs to us alone. It is a perspectival world that we assume is quite different from the perceptual world of other creatures. ${ }^{28}$

24 Morgenröte, sect. 117.

25 The Will to Power, trans. W. Kaufmann and R. J. Hollingdale, New York, 1968, 270.

26 Ibid., 305. 
If we understand Nietzsche's idea of the "falsification" of the world in terms of his analysis of sensation, then we can see that what is is saying is that the world we are acquainted with through sensation and perception is a unique world of qualities that is "true" for us. It is, in effect, a humanized world of experience. In the broadest sense of the term, then, our sensory world is anthropomorphic. It is the inevitable outcome of the scientific interpretation of the physiology of sensation. Despite the dramatic language in which this view is presented, it is not too far removed from very recent arguments that seek to show the "mind-dependent" nature of our experience of the temporal succession of our sensations. ${ }^{27}$ The point is that the human sensory perceptive cannot be transcended. The naiveté of previous thinkers, Nietzsche remarks, was their failure to see that our senses and our "categories of reason" involved "the adjustment of the world for utilitarian ends". Previous thinkers mistakenly believed that they possessed a "criterion" of "truth" and "reality". That is, they tended to "make absolute something conditioned". In effect, an "anthropocentric idiosyncrasy" was taken as the measure of all things. ${ }^{28}$

When he turns his attention to the "mechanistic theory of nature", Nietzsche argues that it is "a regulative principle of method". The mathematical physicists (whose theory of the dynamics of nature he will rely upon) "construct for themselves a force-point world with which they can calculate". The time has come, Nietzsche urges, for physicists, and philosophers as well, to "grasp an hypothesis as an hypothesis and, at the same time, to take it as a guide" for further discovery. ${ }^{29}$ In the same spirit, we may explore the nature of the world by consciously adopting an inevitable human perspective (entailing selectivity, simplification and synthesis) without making truth-claims of an apodictic nature. Philo-

27 Cf. Adolf Grünbaum, "The Meaning of Time", Basic Issues in the Philo. sophy of Time, ed. E. Freeman and W. Sellars, La Salle, Illinois, 1971, 197-208.

28 The Will to Power, 315.

29 Werke, Leipsig, 1901, XIII, 59f, 80-85, 130. 
sophy, like the sciences, should work with provisional assumptions, regulative hypotheses, "conventional fictions" and phenomenalistic posits without assuming that it has access to "pure truth" or "pure knowledge". It is quite clear that the thought-experiments found in the notebooks (Nachlass) can only be understood against the background of Nietzsche's attempt to develop a philosophical interpretation of the implications of the explosion of knowledge in the scientific world of his time. In order to see how and why he projects his principle of the will to power into the inorganic world, we must first turn our attention to the dynamic theory of nature that is the scientific "hypothesis" upon which he builds his philosophical "hypothesis" of a pervasive will-force that acts through dynamic entities.

\section{The Dynamic World-Interpretation}

The extension of the conception of "will to power" into the natural world was a reversion to an earlier, poetic personification of natural forces that understood natural phenomena as manifestations of "pure will". This intuitive feeling for the apparently active forces in nature was reinforced by Nietzsche's reading of the physical scientists of his day. An agnosticism about the ultimate nature of matter was very much "in the air" during the period in which Nietzsche developed his thought. Helmholtz, for example, stressed the postulatory nature of the physicist's speculations about the interior dynamics of the material world. The physicist Lichtenberg waxes philosophical and declares that "we can, properly speaking, know nothing of anything in the world except ourselves and the changes that take place in us". ${ }^{30}$ The attempt to probe the ultimate constituents of the physical world led many nineteenth century physicists away from dogmatic materialism and towards agnosticism or forms of idealism. The scepticism concerning the physicist's interpretation of the

${ }^{30}$ Cited in F. A. Lange, op. cit., iii, 205. 
"text" of nature was not the free invention of Nietzsche. For, it was suggested to him by the physical scientists who were his contemporaries. For, he is only following the suggestions of Helmholtz, Lichtenberg, du Bois-Reymond and others when he remarks that

This world-picture that they sketch differs in no essential way from the subjective [anthropomorphic] world picture. It is only construed with more extended senses, but with our senses nonetheless. ${ }^{31}$

Despite this orientation towards the physical scientific theories, Nietzsche sometimes gives the impression that, because of its "strict methods" and its conscientious avoidance of teleology, the scientific interpretation of the world is a closer approximation to the way of things. What is often mistakenly called "Nietzsche's physics" is not his physics at all. Rather, it is a conglomeration of dominant ideas that were emerging out of nineteenth century physics. The "regulative hypotheses" of the dynamic theory of nature impress him because they avoid both teleology and mechanistic causation. And it is in a dynamic interpretation of the natural world that the concept of "force" (Kraft) is central.

The notes pertaining to physical theory that are found in the Nachlass do not comprise his "later" thought simply because we know that he was already familiar with a number of physical theories as early as 1866. From his earliest exposure to physical theory, Nietzsche was alert to the subtle and not-so-subtle anthropomorphic aspects of theories of nature. In The Joyful Science he frequently chides physicists for ascribing human qualities to the natural world. He charges that the "realists" have not by any means purged themselves or their thought of "the human element". Again, he remarks that we must be on our guard against interpreting nature in

31 The Will to Power, 339. 
terms of our "aesthetic humanities"..$^{32}$ And, as he does so often in the Nachlass, he points to the fictional nature of basic scientific concepts. Against the prevailing view that science "explains" phenomena and their law-like "behavior", he insists that it, at best, describes phenomena and sequences of phenomenal appearances. The sciences do not explain because they operate with

things which do not exist, with lines, surfaces, bodies, atoms, divisible times, divisible spaces - how can explanation ever be possible when we first make everything a conception, our conception! It is sufficient to regard science as the exactest humanizing of things that is possible. ${ }^{33}$

The belief that science is able to attain insight into the 'truth' of things is a "metaphysical belief". In spite of this understanding of science, Nietzsche is very much taken by the emerging dynamic theory of the natural world. So much so that he uses its basic hypotheses as stepping stones to the postulation of a universal will to power. Even though the dynamic theory of nature is not uncritically accepted, and even though Nietzsche is aware of the anthropomorphic character of some of its central notions, he works with it as a kind of provisional "picture" of nature. By describing natural phenomena in terms of interacting dynamic "forces", the dynamic theory of nature is seen as a reasonable hypothesis, a viable "world-interpretation".

Nietzsche believed that the dynamic concept of "force" was going to be "victorious". The central ideas of the "new" physics were that atoms were not static, encapsulated entities, but dynamic centers of force that interacted with other forcecenters in a process of "attraction" and "repulsion". These postulated "point-centers" that lie at the heart of matter are construed as the origin of the macroscopic "effects" that we are able to observe. Although Fechner argued that the physi-

32 Die fröhliche Wissenschaft, 57, p. 109. 
cal concept of force is an expression by which we may represent "the laws of equilibrium and motion", Lange denied that the explanation of action is found in "laws of force" and maintained that such "laws" are really nothing but expressions of "the totality of the relations amongst a group of phenomena". ${ }^{34}$ Nietzsche will agree with Lange that the physical sciences are on firm ground only in regard to "relations" even though bearers of such relations may be introduced "hypothetically".

In his compressed comments on the dynamic theory of the natural world Nietzsche criticizes it because it has not transcended anthropomorphic interpretations. In the first place, the key conceptions of attraction and repulsion are derived from human experience and human relations. The mechanistic notion of dynamic notion is considered as "a translation of the original process into the sign language of sight and touch" ${ }^{35}$ The assumption that forces obey a "law" is a supposition, a "formula" that is put forward as a means of facilitating the description of the entire phenomenon. This formula, as expressed, "corresponds to a complex of initially unknown forces and discharges of force" and does not, in a strict sense, indicate that "forces" act in accordance with it. The conception of dynamic atoms construed as "unities" is a fiction put forward for the purposes of calculation and is derived from an analogy to a putative "ego" that is capable of producing "effects". Even a dynamic mechanics that is expressed in sophisticated terms cannot, in Nietzsche's view, do without "prejudices". For, in order to support such a theory

we always have to stipulate to what extent we are employing two fictions: the concept of motion (taken from our sense language) and the concept of the atom (= unity,

33 Ibid., 112.

34 Lange, op. cit., ii, 395-396.

35 The Will to Power, 334

36 lbid., 335-336. 
deriving from our psychical "experience"): the mechanistic theory presuppose a sense prejudice and a psychological prejudice. ${ }^{37}$

In effect, then, a dynamic mechanics, despite its heroic attempt to present a theory of the natural world in deanthropomorphic terms, ultimately relies upon psychistic fictions and anthropomorphic terminology. Finally, insofar as the principle of causality is applied to phenomena, even the most sophisticated physics relies upon a fundamental "fiction" that is derived from our own "inner phenomenology". In this regard, it is said that the idea of cause-effect relations (e.g., forces producing effects) is based upon "our belief in force and its effect". That is, it is based upon our fallacious belief that in our actions a "feeling of force" is the cause of our actions. We have no experience, Nietzsche argues, of our "forces" compelling something. We only experience that one thing follows another. But we have a propensity to project into this process a "compulsion" that is the psychic origin of our conception of "causality".

Nietzsche argues that an "inner phenomenology" is conditioned by the same cognitive processes of simplification that he believes are operative in our undertanding of external events. The acts or processes we believe take place in our psychic life are also dominated by a process of phenomenal selectivity. For, "everything of which we become conscious is arranged, simplified, schematized, interpreted through and through". ${ }^{39}$ In sum, then, when we think of dynamic force as causing effects we are projecting into natural processes the outcome of a misleading phenomenology of our intentional psychic processes. If this is truly the case, then even a dynamic interpretation of the natural world is contaminated by an anthropomorphism that we have projected into the realm of non-human processes.

\footnotetext{
37 Ibid., 338.

38 Ibid., 350.

99 Ibid., 263-264.
} 
Nietzsche is the first to admit, of course, that in spite of the psychological origin of central concepts in the physical sciences, such primitive assumptions are useful, pragmatic fictions that we probably cannot do without in our calculations and interpretations. In this regard, it is interesting to note that Einstein called attention to the fact the physical concepts of space, time and event have a "psychological origin". ${ }^{40}$ For this reason, as well as for more complex reasons, Einstein avoided any apodictic claim to 'truth', but argued for "the heuristic value of the theory of relativity"."

Before turning to Nietzsche's deliberately anthropomorphic interpretation of the dynamic theory of forces and pointcenters, we may briefly explore the question of the relationship between the relativistic theory of "perspectivalism" and the dynamic interpretation of natural processes that is provisionally adopted as a model of a physical "world-interpretation". It is clear that when Nietzsche claims that each "center of force" interprets the world from its individual perspective, he is relying upon the assumption that the interior structure of "matter" is characterized by energy-quanta or "point-centers" or "forces". Each center of force (or, sometimes, each "constellation of forces") is said to 'picture' or express the world from its own point of reference. There would be no "world" if we deducted such individual perspectives precisely because we would have thereby deducted "relativity". "Reality", Nietzsche concludes, "consists precisely in this particular action and reaction of every individual part toward the whole".42

What Nietzsche seem to have been doing in his notes on physical theory was drawing out all of the implications of what can only be conceived of as a relativistic dynamics. Even though the theory his is working with is a rudimentary one, a rough sketch of a theory, it is clear that Nietzsche is

10 Albert Einstein, Relativity: the Special and General Theory, New York. 1961, 136-139.

41 Ibid., 47-48.

42 The Will to Power, 305. 
seeking to spell out the philosophical implications of a consistent dynamic theory of force-centers. In other words, he has intuitively seen some of the consequences of an inchoate theory of relativity for philosophy.

It has recently been pointed out that the concept of force is "primitive" in twentieth century relativity theory. That is, "the concept of force is primitive" in the sense that it has no "deeper explanation". It is a logically primitive concept the meaning of which can only be clarified by indicating "what sorts of entities have masses or exert forces". Masses and forces cannot be reduced to "anything more physically basic". ${ }^{33}$ Without a technical knowledge of the rich theoretical foundation of a rudimentary theory of relativity, Nietzsche, nonetheless, accepts the notion that "forces" are irreducible physical processes and endeavors to formulate a philosophical response to this assumption. This attempt to formulate a philosophical response to a general physical theory is one that takes place in a universe of discourse that anticipates features of later relativistic dynamics. From his reading of Lange's History of Materialism he was already familiar with Boscovich's relativistic theory of "point-centers"." In addition, he was familiar with Ernst Mach's speculations concerning the possibility of a space with more than three dimensions, as well as with Zöllner's claim that our physical space is non-Euclidean. And there is no doubt that he was impressed by Lange's observation that if such conceptual tendencies continued to develop in the physical sciences then "the whole theory of knowledge must be subjected to an entire revision". ${ }^{45}$ It is no wonder, then, that the rudimentary theory of knowledge that we find, for the most part, in the

${ }^{43}$ Marshall Spector, Methodological Foundations of Relativistic Mechanics, Notre Dame and London, 1972, 159-160.

44 In a forthcoming essay on "Nietzsche and Boscovich's Natural Philosophy" (The Personalist) I've tried to indicate the precise points of resem. blance between Boscovich's original, purely theoretical analysis of the dynamics of natural processes and Nietzsche's understanding of the dynamic interpretation of nature in the Nachlass.

45 Lange, op. cit., ii, 388 . 
Nachlass is incomplete and tangled. For, Nietzsche was apparently trying to formulate a theory of knowledge on the basis of a relativistic dynamics that was still in its infancy, that was still in a process of development. Provisionally adopting a physical world-interpretation that postulated a vast multiplicity of force-centers or "power-centers", he is led to proclaim that the constant action and reaction of such centers of force is "reality". But Nietzsche, despite his long struggle against metaphysical speculation, is not satisfied with the advancement of what amounts to a process theory of actuality. ${ }^{17}$

Nietzsche sought to extend his thought beyond the limits of a philosophical interpretation of the implications of a dynamic physics because he saw that mechanics gives us only "quantities" or, more accurately, mathematic and symbolic representations of quantities or quantitative processes. He came to see that a "mechanistic interpretation" actually

desires nothing but quantities; but force is to be found in quality. Mechanistic theory can therefore only describe processes, not explain them. ${ }^{18}$

The description of physical processes in mathematical terms is a form of "calculation" by which complex processes are simplified for heuristic purposes. The physical description of "the world" is, in point of fact, a "symbolization of the world". ${ }^{19}$ Despite the heuristic value of quantitative representations of natural processes, we tend to translate quantitative differences into qualitative ones. The phenomenologically diverse qualitative world that we experience is construed as a schematization, a simplification, an arrangement of phenomena that is not "true". Despite this, the

\footnotetext{
46 We may compare Einstein's remark that the "real external world" is the "sum total" of all "space-time events". Op. cit., 140-141.

47 At one point in his notes he reminds himself to "note well": Die Prozesse als 'Wesen'. In effect, he is alluding to the idea that processes are the essence of reality. Cf. The $\mathbb{W}$ ill to Power, 346.

48 The Will to Power, 349.

49 Ibid., 304.
} 
apprehension of qualities is, for us, an ineluctable "perspective truth" ${ }^{50}$ By means of weighing, calculating and reckoning our "knowledge" is expressed in quantitative terms. But our typical human perspective is clearly qualitative in nature. Therefore, even though the world that we are familiar with through sensory experience and cognitive organization is a "falsified" world, is not, strictly speaking, "reality", it is a humanized world that preserves the qualitative diversity of our experiences. At this point, Nietzsche raises the following question: "Might not all quantities be signs of qualities?" Denying that all qualities can be reduced to quantities (except for purposes of calculation, conceptual efficiency, etc.), he avers that the qualitative world accompanies the quantitative one as "an analogy". In order to understand truly the quantitative, dynamic world-interpretation of physics, we must translate it into human, qualitative terms.

The conception of a "denatured" force, a force we cannot even imagine, is quite unsatisfactory. We have a natural propensity to want to go beyond the mathematical formulae that symbolize forces, to seek an answer to the more basic question: what is force? We want, that is, a "deeper explanation" of force. But this cannot be provided by physical theory itself. Such an explanation cannot be found either in classical or relativistic dynamics. It is in his attempt to provide a qualitative interpretation of the quantitative conception of "force" that Nietzsche is led to put forward his "hypothesis" of the Wille zur Macht. In terms of his own epistemological standpoint, this hypothesis was intended as a "humanization" of the physicists' concepts of force or as a qualititave analogy to quantitative units of "power".

Both in the Nachlass and in Beyond Good and Evil Nietzsche states quite plainly why he projected a will to power into the inorganic realm. The implications of his having done so have rarely been discerned. In the first place, the ascrip-

50 Ibid.

51 lbid. 
tion of a "will to power" to non-human, organic beings is itself a species of anthropormorphic interpretation. For, we certainly do not know that non-human organisms are capable of the kind of volitional intentionality that we assume (on the basis of our "phenomenology" of intentional action) we are capable of initiating. When Nietzsche finally turns to the inorganic world and tries to understand the meaning of "force", he ascribes "will" to the interior dynamics of "force-centers". This is explicitly an anthropomorphic interpretation. The concept of force in the physical sciences has to be completed, Nietzsche argues, by means of a kind of philosophical thoughtexperiment. That is, "an inner will must be ascribed to it, which I designate as "will to power", i.e., as an insatiable desire to manifiest power; or as the employment and exercise of power, as a creative drive". ${ }^{52}$ This interpretation of the meaning of the physicists' concept of force for us is based upon the assumption that "appearances", motions and "laws" are "symptoms of an inner event" and that man is used as an "analogy" for this purpose. Furthermore, this postulated "will to power" (even though it accounts for "change") is not, strictly speaking, a "being" or a "becoming". Rather, it is a "pathos". ${ }^{53}$ This refinement of his thesis only deepens the human analogy insofar as the very concept of pathos (passion, suffering, feeling) is one that has distinctly human associations. Even though we may, by transference, attribute pathos to sentient beings in the sense that they may be said to suffer or undergo something, its essential meaning is rooted in human feeling. What Nietzsche proposes, then, is an anthropomorphic interpretation of the nature or "essence" of the will to power. The rationale for postulating a will to power acting through the inorganic order is the humanization of the physical scientific conception of Kraft. The "inner event" that is this will to power is construed as analogous to ostensible human willing. Finally, the nature of this will

5: Ibid., 333.

ธง Ibid., 339. 
to power is described in terms of a virtually exclusive human state of being. In the hypothetical argument for a universal will to power presented in Beyond Good and Evil the paradoxical nature of this hypothesis will be even more apparent.

In a central passage in Beyond Good and Evil it is argued that if we grant that the sole data that are given to us as real are our own desires, passions and drives, and if we assume that we can discover no another reality than our own "drives", then would it not be plausible to assume, on the basis of our immediate understanding of our passions, drives and desires, that the "mechanistic" or "material" world could be understood in similar terms? Would it not be reasonable to maintain that physical reality may be analogous to our own inner world of "affects"? Perhaps the physical world interpreted by the scientists is a "more primitive world of affects in which everything still lies contained in a powerful unity before it undergoes ramifications and developments in the organic process". Now, in order to understand this operation of a primitive "force", would it not be plausible to assume that "the will is efficient"? If our belief in causality is itself based upon our belief in the causal power of our will, could we not grant that this primitive will is causally efficacious? Granting the above, we could interpret "mechanical occurrences" or the active force in them in terms of a "will-force" or "will-effects". Again, if our drives, desires and passions are understood as ramifications of "one basic form of the will", the "will to power", then we could trace all organic and inorganic functions to this will to power. All efficient force, then, would be univocally construed as determined by this Wille zur Macht. This "assertion" or "hypothesis" serves to represent the world seen from within -Die Welt von innen gesehen- or pure will to power itself. ${ }^{54}$

It is clear that this interpretation of the human meaning of the "mechanistic world" cannot be understood, in Nietzsche's own terms, as a species of knowledge. A hypothetical

$\therefore$ Werke in Drei Bänden, II, 601 . 
will to power could never be a phenomenal appearance for us nor could it be said to exist insofar as Nietzsche specifically holds that we do not have "knowledge" of any so-called unconditioned reality. ${ }^{55}$ The hypothetical form of his argument indicates that Nietzsche is putting forward his interpretation of the human meaning of the mechanistic worldinterpretation of the physical sciences. In addition, of course, the hypothetical argument for the universality of the will to power is explicitly modeled upon the assumption of a willforce operative in the passions, desires, drives and action of man.

Most of the central assumptions that are incorporated into Nietzsche's hypothetical argument are described (in the Nachlass, The Joyful Wisdom and Twilight of the Idols) as "fictions", "regulative fictions" or as fallacious notions. There is, Nietzsche insist, no "will" that is active in a supposed "subject" or "ego". The belief that the will is causally efficacious is, according to Nietzsche, a notorious fallacy. The very notion of a "will force" that is capable of producing effects is undermined by Nietzsche's critical analyses of the origin of such a belief. He insists often enough that the idea of cause-effect relations is based upon a fallacious "internal phenomenology" that assumes that our "felling of force" is a "cause" of our actions. There is no "subject" that is a causal agent that intends an action. Such an idea is a psychistic fiction. It is, in fact, one of the origins of the false, but practically useful, conception of causality. The terms that are used in the hypothetical argument for a universal will to power acting through all entities indicate that he is not stating any "agreement" with a known or knowable "reality". The explicit reliance on a human model, the dependence upon repeatedly criticized notions about the causal efficacy of "will", indicate that the extension of a will to power into the inner dynamics of nature is a fictional interpretation put forward from the human perspective in order to make the

s5 The Will to Power, 301. 
natural world and its processes intelligible to us in a human, qualitative sense. The conception of the Wille zur Macht is a creative, metaphorical construction of a thoroughly anthropomorphic vision of "reality". It is a metaphorical picture of "reality" that is designed, as all metaphorical images are, to give us a humanized portrait of the real.

Nietzsche believed that a strictly "mechanical" worldinterpretation would yield a "meaningless world". ${ }^{56}$ The reduction of the world to quantitative terms would be like music reduced to what can be counted, calculated, measured or formulated. Music is a complex qualitative phenomenon that can only be appreciated or valued as a whole, as a totality. The postulation of a universal will to power, then, is Nietzsche's qualitative interpretation of the quantitative world depicted in the dynamic theory of nature. In terms of all of its characteristics, in terms of the elements that comprise its "nature" and "activity", the conception of the will to power is a radically anthropomorphic notion. Few thinkers have uncovered and attacked anthropomorphism as much as Nietzsche has. And few philosophers have shown, in such a dramatic way, that, in the final analysis, it cannot be transcended.

The circle of Nietzsche's thought moves from the human to the deanthropomorphic limits of the quantified world of dynamic physical theory back to the human standpoint. Neither our senses, nor our reason, nor our philosophical imagination can transcend the inevitability of a humanizing process that haunts our attempts to understand ourselves, the experiential world, the physical structure of reality and the nature of "ultimate reality".

The same simplifying, organizing, schematizing process that pervades all knowing for Nietzsche is at work, as we have seen, in our attempts to interpret our own nature. The inner world, too, is phenomenal, a set of "appearances" constituted

56 Die fröhliche Wissenschaft, 373: “...eine essentiell mechanische Welt wäre eine essentiell sinnlose Welt!" 
by our interpretative understanding. There is nothing, Nietzsche believes, as deceptive as the famous "inner sense". For, our "inner experiences" enter consciousness after they have been simplified and schematized in such a way that a "language" is found that the individual understand. This understanding is the expression of something "new" in the language of something with which we are "familiar". Homo natura is, like nature as a whole, an "original text" that we interpret in such a way that we can function effectively, live and discharge our energies in a creative, life-enhancing way.

Despite his attempt to achieve a transhuman insight into the heart of "reality", Nietzsche ends by offering us a personified, voluntaristic conception of "force" or "power" that is not only modeled on man, but is based upon a notion of psychic intentionality and action that is the product of an "inner phenomenology" that Nietzsche presents as if it, too, were an inevitable, if misleading, feature of our interpretative understanding and the simplifying, metaphorical nature of language. It would seem that the understanding of the world "from within" as will to power is itself based upon a hypothetical, not to say "fictional", perspectival interpretation of human nature! In the final analysis, man is the text and the interpreter of the text.

эт The Will to Power, 265-266. 
Uno de los temas recurrentes en la filosofía de Nietzsche es el de la influencia del antropomorfismo sobre nuestra concepción de la verdad y la realidad. La "humanización" del mundo en aras de la vida y la de la naturaleza en aras de su dominio son ideas centrales en su pensamiento. Desde sus primeros escritos examina el lenguaje y ciertos conceptos que aceptamos acríticamente y descubre una tendencia aparentemente inevitable a describir y entender lo no humano en términos de actitudes, sentimientos, impulsos y emociones humanas. Es más, duda de que seamos capaces de entender algo a menos que usemos nociones derivadas de nuestras relaciones sociales, de nuestra auto-reflexión o del lenguaje que empleamos para describir el "yo". La actitud de Nietzsche frente a la tendencia del pensamiento humano a la antropomorfización es clara: acepta que es inevitable y presenta su propia concepción de la realidad como "voluntad de poder" sobre la base de un antropomorfismo conscientemente adoptado. El objetivo de este artículo es mostrar cómo el antropomorfismo -que Nietzsche descubrió tan agudamente en el pensamiento de otrosestorbó su intento de trascender el punto de vista humano y lograr una visión de una presunta "realidad" deantropomórfica.

El artículo de George J. Stack se divide en tres partes. La primera la podemos llamar lenguaje y verdad. El lenguaje, según Nietzsche, no puede representar la naturaleza "verdadera" de las cosas, no puede expresar la "verdad pura" y tampoco puede "pintar" o des. cribir la realidad. Sólo puede usarse para designar "las relaciones de las cosas con el hombre" y para expresar esas relaciones en tér. minos metafóricos. La verdad es, primariamente, una convención socialmente determinada que requiere que usemos "metáforas acostumbradas". La verdad es "una flota en movimiento de metáforas, metonimias y antropomorfismos", una "suma de relaciones humanas" que se "encarece, traspone y embellece poética y retóricamente". Nietzsche da tres razones por las cuales el lenguaje es inadecuado para "pintar" la realidad: (1) los lenguajes usan abstracciones, asumen "identidades" simplificadoras y son incapaces de emplearse para describir la riqueza, diversidad y complejidad de la experiencia inmediata; (2) los lenguajes emplean metáforas y antropomorfismos que originan una pintura de la realidad poética y humanizada que es, presumiblemente, "falsa", y (3) el lenguaje se usa para describir "apariencias", que son constituidas por nuestra "organización", y no puede usarse para describir las "cosas en si mismas". Si el lenguaje 
tiene la estructura que Nietzsche le atribuye, entonces todo intento de expresar la "verdad" por medio de él está condenado al fracaso.

Lo que Nietzsche dice acerca de los usos de los lenguajes naturales vale igualmente para la expresión lingüística de las "verdades" metafísicas. De ahí surge su agnosticismo acerca de la verdad de las tesis metafísicas. Pero Nietzsche no sólo rechaza el conocimiento metafísico, sino que rechaza, además, el "conocimiento empírico"; lo cual muestra Stack mediante un estudio cuidadoso del análisis crítico que Nietzsche hace de la interpretación científica del "mundo". La conclusión de este análisis es que la "interpretación" científica del "mundo" también está infectada por el "elemento antropomórfico en todo conocimiento". Por tanto, no puede decirse que la ciencia muestre una "pintura" objetiva de la realidad. En suma, el mundo simplificado, ordenado y organizado por la "organización" cognitiva y sensible del hombre, por sus conceptos y lenguajes, por sus categorías científicas y filosóficas, es necesariamente un "mundo humanizado". De esta manera, según Nietzsche, el pensamiento no puede trascender el punto de vista humano ni escapar a su perspectiva antropocéntrica.

La tesis nietzscheana de la inevitabilidad de una interpretación antropomórfica del mundo es crucial para su "hipótesis" de la "voluntad de poder" como un principio metafísico de explicación. La idea de la "voluntad de poder" aparece prefigurada en el ensayo inédito "El debate de Homero" y explícita en Así habló Zaratustra, donde afirma que la esencia del hombre es la "voluntad de poder". La extensión de la "voluntad de poder" al campo de los procesos inorgánicos no es un producto de la que llaman su filosofía "posterior". Por el contrario, su teoría de la universalidad de la voluntad de poder complemen. ta sentimientos expresados por Nietzsche en las etapas tempranas de su reflexión y concuerda con su descubrimiento de una voluntad de poder psicológica en el hombre.

La segunda parte del artículo se titula sensación y antropomorfismo. Para Nietzsche, el proceso de la sensación es activo porque no hay una recepción pasiva de "impresiones sensibles". Por el contrario, existe una actividad que es selectiva, simplificadora y que está condicionada por intereses, emociones e impulsos, la cual da forma a la experiencia sensible. Así, el mundo sobre el cual han actuado nuestro ojo y nuestra psicología es un mundo para nosotros, un mundo que hemos formado por medio de nuestros sentidos en aras de la simplificación y la satisfacción de nuestras necesidades pragmáticas. Ahora bien, "si todas nuestras categorías de razón tienen un origen sensible", si se derivan del "mundo empírico" que experimentamos, entonces el mundo "externo" que conocemos está estructurado de acuerdo con las limitaciones de nuestros sentidos. En suma, el mundo 
cualitativo que experimentamos a través de los diversos sentidos nos pertenece solamente a nosotros solos. Es un mundo con ciertas perspectivas que, asumimos, es completamente diferente del mundo perceptual de otras criaturas. Este mundo es, por tanto, "verdadero" para nosotros; es un mundo de experiencia humanizada. Nuestro mundo sensible es antropomórfico y la percepción sensible del hombre no puede trascenderse. Nuestros sentidos y "categorías de razón" implican el ordenamiento del mundo con fines utilitarios; podemos explorar la naturaleza del mundo adoptando, conscientemente, una perspectiva inevitablemente humaua sin pretender verdades de tipo apodictico ni "hacer absoluto algo condicionado". La filosofía - como la ciencia- debe trabajar con supuestos provisionales, hipótesis regulativas, ficciones convencionales y principios fenomenológicos, sin suponer que tiene acceso a la "verdad pura" o al "conocimiento puro".

La tercera y última parte se intitula la interpretación dinámica del mundo. En esta parte el autor del artículo muestra cómo y por qué Nietzsche proyecta su principio de la "voluntad de poder" al mundo inorgánico. Esto lo hace examinando la teoría dinámica de la naturaleza que es la "hipótesis" cientifica sobre la cual Nietzsche edifica su "hipótesis" filosófica de una voluntad-fuerza expansiva que actúa a través de las entidades dinámicas.

[Sebastián Lamoyi V.] 